Contents List available at VOLKSON PRESS
Education, Culture and Social Development (ECSD)
DoI : http://doi.org/10.26480/icecsd.01.2018.51.52
Journal Homepage: : https://topicsonsocialdevelop.com/

\title{
ANALYSIS OF THE HEROINE ELIZA DOOLITTLE IN THE MUSICAL OF MY FAIR LADY
}

\author{
Xiang Hongxing *, Yuan Zhen, Dai Chenyan \\ Shanghai Normal University Tianhua College, North Shengxin Rd. Jiading, Shanghai, China \\ *Corresponding Author Email: hongxing33@126.com
}

This is an open access article distributed under the Creative Commons Attribution License, which permits unrestricted use, distribution, and reproduction in any medium, provided the original work is properly cited

\section{ARTICLE DETAILS $\quad$ ABSTRACT}

\section{Article History:}

Received 12 November 2017

Accepted 12 December 2017

Available online 1 January 2018
This paper aims to analyze Eliza Doolittle, the heroine in the musical of My Fair Lady in terms of highest task. Through careful review of the plots and songs, the researcher illustrates the process of how Eliza finds and achieves her highest task. This paper shall contribute to better understanding of Eliza's character and further appreciation of this musical.

\section{KEYWORDS}

Musical, highest task, musical appreciation.

\section{INTRODUCTION}

The musical My Fair Lady (Music by FREDERICK LOEWE, Book and Lyrics by Alan Jay Lerner) premiered at The Helinger Theater in New York on March 15, 1956. The musical revolves around stories between a flower peddler named Eliza and a linguist Henry Higgins. Eliza happened to find her poor English pronunciation being recorded by Prof. Higgins when Colonel Pickering bought flowers near a theater [1]. The conversation between such two upper class gentlemen irritated Eliza, leading to confrontation, which revealed Prof. Higgins identity, profession, and pursuit as a linguist as well as his acquaintance with Colonel Pickering. This musical is about the transformation of Eliza's phonetic competency and her love with Prof. Higgins.

In order to analyze the female protagonist in the play, I found the musical film starring Audrey Hepburn and the Vocal Score [2]. According to these two materials, the play has two acts, but these two versions present the scenes in different orders. The acts analyzed in this article are based on the movie version of the musical starring Audrey Hepburn. There are nine scenes in the first act, and another nine in the second act. The heroine performed a total of six different songs, but in the first act, two songs appeared repeatedly in the second act.

In sequence, the title and scene of each piece are: Outside the Opera House, Covent Garden, Wouldn't It Be Lovely? in Scene One of Act One, Just You Wait, The Rain In Spain and I Could Have Danced All Night in Scene Five of Act One (at Higgins' Study), Reprise of Just You Wait in Scene Three of Act Two (at Higgins' Study), Show me in Scene Four of Act Two (outside Higgins' House, Wimpole Street), Wouldn't It Be Lovely? echoed around the heroine in Scene Five of Act Two (at Flower Market Of Covent Garden), and Without You in Scene Seven of Act Two (at The Conservatory Of Mrs. Higgins' House). Next, I will analyze the heroine Eliza Doolittle in the firstperson tone.

\section{ANALYSIS OF ELIZA IN THE MUSICAL OF MY FAIR LADY}

My name is Eliza Doolittle and I am 21 years old. My height is five feet and seven inches. My body is well-balanced, graceful, and fair-skinned. I am a proletariat and Christian. I am a person with simple morality like my father. What is simple morality? For example, in my world, I can tell the difference between the good and bad, kind and evil. I also admire truth, goodness and beauty. Yet to survive, I didn't adhere to so many moral constraints as a middle class [3]. As long as I don't violate the law, I don't mind talking glibly occasionally to sell more flowers. I am casual in manners, such as wiping away tears and snot with my sleeves.

Yet I am a good girl, living in Lisson Grove. I haven't had good education since childhood. So I speak with Lisson Grove accent. In the first scene of the first act, Professor Higgins recorded the characteristics of my accentthe vowel / $\mathrm{h} /$ is often omitted; sometimes also /h/ is added to some word that does not have it. For example, "Higgins" is pronounced as "iggins" and "ever" is pronounced as "hever"; the vowel of /ai/ is mispronounced as /i/, and the pronunciation of / əひ / is made into / a /.

However, I did not feel unhappy because I was born poor, which is similar to my father. I am optimistic and unyielding, with certain independent thinking and acute observation on development and changes. My life has been subject to constant development, and it is closely related to the social environment at that time. There is a great disparity between the rich and the poor in society, where I long to earn a living as a flower vendor, and of course I hope that it will be better. So I have a blurred highest task-- I hope to live at a warm home, and have my own warm and beautiful little room, where there is chocolate and warm sunshine, and where everything is very pleasant! The most important thing is to have a husband who loves you! This is the general task shown from Wouldn't It Be Lovely? in Scene One of Act One (outside the Opera House, Covent Garden)

How can I achieve my wish? I recall Professor Higgins's words when we first met at the theater where I was selling flowers. He was speaking to me and Colonel Pickering. He said that he could correct my English pronunciation within six months and that I would participate in the embassy dance like a Duchess, and so that I can work as the lady's servant or shop clerk. So, I go to his home hoping to learn from him. During the course of my studies, I experience Professor Higgins's harshness and ruthlessness [4]. I really can't wait to execute him to death. So, I sang Just You Wait in the Higgins' Study in Scene Five of Act One to show my dissatisfaction. The professor teaches me phonetics in different ways around the clock, and it doesn't work at all. I am tired and desperate. It is late at night, when I tell the professor that I can't make it. The professor already sleeps, but he gets up and sits with me. That night he talks with me heart-to-heart: "The majesty and grandeur of the English language...is the 
greatest possession we have. The noblest thoughts that ever flowed through the hearts of men are contained in its extraordinary, imaginative, and musical mixtures of sounds. And that's what you've set yourself out to conquer, Eliza. And conquer it you will."

At that moment I suddenly feels that the professor is so genial and genuine, trusting me so much with encouragement. My verbal intelligence is stimulated. When I tries to make a sound, I succeed. The professor weariness suddenly disappears and starts testing me other sounds. I make it; I do it all correct! The professor, colonel and I are so excited, singing and dancing. In this scene (Scene Five of Act One at Higgins' Study), I sing The Rain in Spain, and when I am singing, I feel that the professor has come down from the "altar". He does not have an aggressive temper; Nor does he show the usual cold arrogance and proud. I feel his recognition and encouragement. Suddenly he hugs me and dances with me. I am really happy. Now I begin to have a crush on him rather than antipathy as before. Then when they return to the bedrooms, my heart is opened and sing $I$ Could Have Danced All Night in Scene Five of Act One at Higgins' Study. I know that I have found my highest task that is to be with Professor Higgins.

Six weeks after the embarrassment at horse racing, he takes me to the embassy ball. My splendid conversation makes his phonetic student Zoltan Karpathy mistakenly believe that I am a princess come from the Hungarian royal family. When he returns home, he completely ignores my feelings, immersed in praises by other people. I realize that it is full of ups and downs to accomplish my highest task. The biggest obstacle comes from Professor Higgins. He never opens his heart to me, always treating me as a flower girl. So, after everyone takes a rest, I no longer hold back my emotions, and have a dispute with him, and sing Reprise: Just You Wait in Scene Three of Act Two (at Higgins' Study) and leave him. When I come back to where I was selling flowers, the music Wouldn't It Be Lovely? echoes in my ears in Scene Five of Act Two (at Flower Market of Covent Garden). I know I love him, so I come to Mrs. Higgins's house, only to find out that Professor has come to his mother's house because he was looking for me everywhere.

When we meet, we have a little confrontation, thanks to which I pour out unpleasant feelings towards him, and am determined to be independent. I sing Without you in Scene Seven of Act Two (at the Conservatory of Mrs. Higgins' House). However, he does not really feel happy for my independence. Instead, he rudely interrupts my singing. He also said reluctantly that he knew I could do it. In fact, at that moment, I realize that he cares about me and cannot live without me. However, after he interrupted my singing, I bluff him, saying, "Good-bye, Professor! You will not see me again." Under my stimulation, the professor goes home, sits in the chair, and listens to my recordings, regretting that he was not able to make me stay. It was at this time that I returned to him.

\section{CONCLUSION}

In summary, this is an analysis of Eliza Doolittle in Musical of My Fair Lady in terms of highest task, which shall contribute to further appreciation of this piece and better understanding of Eliza's character.

\section{REFERENCES}

[1] Laufe, A. 1977. Broadway's greatest musicals. Funk \& Wagnalls Company.

[2] Lerner, A.J., Loewe, F., Previn, A. 1997. My fair lady. Penguin.

[3] Garebian, K. 1998. The Making of My Fair Lady. Mosaic Press.

[4] Vacca, J., Feinberg, E. 2000. Why Can't Families Be More Like Us? Henry Higgins Confronts Eliza Doolittle in the World of Early Intervention. Infants and Young Children, 13 (1), 40-48. 